\title{
AKIL HASTASI : TANIMLAMASI YARATTIĞI RAHATSIZLIK VE DAVRANIŞLARI ILE BAŞA ÇIKMA
}

\author{
A. Nuray KARANCl*, Doğan KǑKOEMiR*"
}

- Akıl hastası tanısı alan kışılerın, tehlıkelı, ne yapacakları bellı olmayan ve korkulacak kışıler oldukları toplumda varolan beklentlerdır Akıl hastası tanımı alan bır kışının ozellıklen, aynı ozelıklen gosteren fakat fızıksel bır rahatsızıı̆ı olduğu sơylenen kışılere góre daha olumsuz olarak algılanmaktadır Akıl hastalarına karşı tutumların yaşı ve eğıtım cuzeyl duşuk kesimlerde daha olumsuz olduğu, akıl hastası bırını tanıyıp tanımamanın ıse bu tutumlarda değışıklık yaratmadığı bulunnusştur (Arkar ve Eker, 1992, Morrison, Man ve Drumheller, 1994, Scoall ve Holtgraves 1992)

"Etıketleme perspektıfinden bakıldığında, "akıl hastası" olan kışının bu olumsuz beklentilerden etkılendığı, duygu ve davranışlarının ona gore şekılendığı ve bu etkı ıle başa çıkmanın guç olduğu one surulmektedit (Lınk, 1987, Lınk, Mirotznik ve Cullen 1991)

* Akıl hastatığına karşı olan tutumlar, hastalıkla ıgılı bılgı ve beklentılerte ılışkı olabıı Halkın akıl hastaaı̆̆ı konusunda eğgııımesının sağlanması ıçın akıl hastalarına karşı olan bekientierın ve tutumlaIIn araştırılması gerekmektedır (Eker, 1991, Socall ve Holtgraves, 1992) Bu açıdan halkın akıl hasta. larından ne tur davranışıarı bekledıklerını, bu davranışların onlarda yaratacağı rahatsızık ve başa çıkma beklentılerını incelemek, akıl hastalığı konusundakı halk eğıtım çalışmalarının temelını oluşturabilır

- Prof Dr ODTU Psikoloj Bolumu

-* Araştırna Gorevissi ODTU Psikoloji Bolumu 


$\begin{array}{llll}K & R & \text { I } & \text { Z }\end{array}$

\section{Veri Toplama Aracı}

Araştırmada kişilere 47 cômleden oluşan, değjşik davranışları omekleyen bir aile anketi verilmiştir (Barrowclough ve Tarrier, 1987), ve deneklerden her bir davranışı (a) "akıl hastası" bir kişinin ne sıklıkla gösterdiği, (b) bunun denek için ne kadar rahatsız edici olduğu ve (c) bu durumla deneğin kendisinin ne kadar başa çıkabileceð̆i konularındaki düşüncelerini 5'li Likert tipi bir olçekte değerlendirmeleri istenmiştir. Akıl hastalığıyla ilgili herhangi bir bilgi verilmemiş, böylece kişilerin zihinlerindeki genel "akıl hastası" imajını kullanmalarına olanak sağlanmıştır.

\section{"Akıt Hastası" Davranışlan}

(Bu davranış ne sıklıkla olur?)

\section{Faktör Anallzi Sonuçjari}

(Bütün davranış ơmekleri için Varimax rotasyon kullantlarak faktör analiz yapildı. Faktör katsayıları .40 ve üstü olan davranışlar göz ơnünde bulunduruldu.)

\section{Faktör 1 (19.8 \%) Olumsuz Duygular}

Mutsuz olur veya bunalima girer (.69)

Panik ve kaygı dönemleri vardır (.65)

Çok fazla endişelenir (.63)

Olağanın dışında korkuları vardır (.58)

Çok uzun süreler içine kapanıp kendi kendine kalır (.57)

Garip huyları veya alışkanlıkları vardı $(.55)$

Tuhat davranır (.50)

Kendisi ile konuşulunca saçma sapan şeyler söyler $(.46)$

Insaniarın ona karşı olduğunu düşünür (.44)

Uzun zaman yalnız başına kalır (.43)

Bazı şeyleri sadece belirli tarzda yapma alışkanirğı vardır (.42)

Başkalarını suçlar veya tehdit eder (.41)

\section{Faktơr $2(6.2 \%)$ Saldırgan/ık}

Küfreder yada başkalarına kaba davranır (.73)

Başkaları ile tartışır veya kavga eder (.67) (.61)

Zarar vericidir evedeki eşyalara vurur devirir

Başkalarını suçlar veya tehdit eder (.60)

Çok çabuk canı sıkılır veya çabuk kızar (.53)

Başkalarına vurur veya canlarını acıtır $(.46)$ $\operatorname{tir}(.45)$

Görünümü davranışları veya hareketleri acayip.

Parasını boşuna harcar (.42)

Gürültü yapar veya bağırır (.40)

Faktör 3 (4.5\%) Antisosyal Davranıs

Fazla içki içer (.76)

Eve yeterince para vermez (.62)

Uygunsuz kişilerle birlikte olur (.59)

Gereksiz yere ilaç kulianılır (.52)

Iştahı azdir veya yemek yemek istemez (.47)

Uykuya dalmakta güçlük çeker (.46)

Geceleri geç vakitlere kadar eve gelmez (.41)

Faktör 4 (4.4\%) Oz Bakm He Hgill Sorunlar

Hafızası ile ilgili belirgin zorlukları vardır (.65)

Kendini veya dikkatini birşeye veremez (.56)

llaç almayı reddeder (.51)

Ne yapacağı belli olmaz veya düşünmeden davranır (.46)

Temiz ve düzenli değildir (.46)

Yerinde duramaz (.45)

Faktör 5 (4.2\%) lletişim Bozukluklar

Ona birşey söylendiğinde cevap vermez (.65)

Kendi kendine konuşur veya güler (.61)

Kendi kendine hayali arkadaşlarla konuşur (.51)

Çok kolay sıkılır veya kedini oyalamakta güçlük çeker $(\cdot .43)$

\section{Faktör 6 (4.0\%) lçine Kapanıklik}

Birşeyler yaparken yavaştır (.63)

Fazla birşey yapmadan öylece oturur (.59)

Insanlarla karşılaşmaktan korkar (.42)

Arkadaşlarıyla veya akrabalarıyla ilgilenmez (.40) 
Faktor 7 (3.5\%) Yakınma/Ş/kayet

Gereğınden fazla titızdır ve kolay kolay beðenmez (56) (55)

Başağrısı veya dığer ağrılardan şıkayet eder

Fazla sóylenır ( 54)

\section{AKIL HASTASI TANIMLAMASI}

\section{Akıl Hastaları Hangi Davranışlan Gösterır?}

\begin{tabular}{|l|c|c|}
\hline Faktor & Ortaiama & Standart Kayma \\
\hline Olumsuz Duygular & $324_{\mathrm{a}}$ & 640 \\
\hline Oz Bakım ıle llgıılı Sorunlar & $321_{\mathrm{a}}$ & 714 \\
\hline lçıne Kapanıkık & $306_{\mathrm{b}}$ & 783 \\
\hline Iletışım Bozuklukları & $299_{\mathrm{b}}$ & 726 \\
\hline Saldırganlık & $288_{\mathrm{c}}$ & 659 \\
\hline Yıkanma/Şıkayet & $278_{\mathrm{c}}$ & 802 \\
\hline Antısosyat Davranış & $236_{\mathrm{d}}$ & 708 \\
\hline
\end{tabular}

Faktor puanları 5'li Lıkert tıpı ölçek ustunden hesaplanmıştır, (5= her zaman, $1=$ hıç bır zaman)

Tekrarlanan çok değışkenlı varyans analızı (repeated MANOVA) sonucunda, derieğın cinsıyetının ve akı! hastası bırını tanıyıp tanımamasının faktör puaniarı uzerınde bır etkısı olmadığı bulunmuş, fakat faktorler arasında anlamlı bır farklılıga rastlanmıştır ( $F=2649, p<001)$

Birbırlerınden istatıstıksel olarak aniamiı farklıliklar gosteren ortalamalar tabloda değışık harflerle gosterılmıştır

AKIL HASTASI DAVRANIŞLARININ YARATTIGI RAHATSIZLIK

Akıl Hastalarının Davranışları Sizi Ne Kadar Rahatsız Eder?

\begin{tabular}{|l|c|c|}
\hline Faktor & Ortalama & Standart Kayma \\
\hline Saldısganlık & $320_{\mathrm{a}}$ & 768 \\
\hline Oz Bakım ıle Ilģıı Soruntar & $303_{\mathrm{b}}$ & 703 \\
\hline Antısosyal Davranış & $287_{\mathrm{C}}$ & 785 \\
\hline OJumsuz Duyguiar & $286_{\mathrm{c}}$ & 710 \\
\hline Yakınma / Şıkayet & $282_{\mathrm{c}}$ & 747 \\
\hline Iletışım Eozuklıkları & $243_{\mathrm{d}}$ & 859 \\
\hline Içıne Kapanıklık & $217_{\mathrm{d}}$ & 769 \\
\hline
\end{tabular}

Faktör puanları 5'lı Likert tipı Olçek ustunden hesaplanmıştır, (5 = pek çok rahatsız eder, 1 = hıç rahatsiz etmez)

Tekrarlanan çok değışkenlı varyans analızı (repeated MANOVA) soncunda; deneğın cınsıyetının ve akıl hastası bırını tanıyıp tanımamasının faktor puanları uzerınde bır etkısı olmadığı bulunmuş, fakat faktörler arasında anlamlı bır farklılıga rastlanmıştır ( $F=22$ 27, $p<001)$

Bibırlerinden istatıstıksel olarak anlamlı farklııklas gösteren ortalamalar tabloda değışık harflerle gősterımıştır.

\section{ÇIKMA}

AKIL HASTASI DAVRANIŞLARI ILE BAŞA

Akıl Hastalarının Davranışlan lie Me Kadar Başa Çıkabilirsıniz?

\begin{tabular}{|c|c|c|}
\hline Faktör & Ortalama & Standart Kayma \\
\hline Oz Bakım le llgilı Soruniar & 271 & 727 \\
\hline Yakinma/şłkayet & 270 & 753 \\
\hline Antısosyal Davranış & 263 & 891 \\
\hline Iletışım Bozukluklart & 261 & 799 \\
\hline İ̧ane Kapanıklık & 260 & 828 \\
\hline Olumsuz Duygular & 248 & 735 \\
\hline Saldirganlık & 247 & 713 \\
\hline
\end{tabular}

Faktor puanları 5'ı Lıkert tupi olçek ustunden hesaplanmışı̆, (5 = çok ıyı başa çıkarım, 1 = hıç başa çıkamam)

Tekrarlanan çok đeğışkenlı varyans analızı (repeated MANOVA) sonucunda, deneğın cınsıyetının ve akıl hastası bırını tanıyıp tanımamasının faktor puanları uzerınde bır etkısı olmadığı bulunmuş, faktórler arasında da aniamí bır farkilığa rastlanmamıştır

\section{Diger Bulgular}

Yaş lerledıkçe denekler, Antısosyal Davranış ve Içıne Kapanıklık davranışının akıl hastalarında daha sık gozlenmesını bekledıklerını belırtmışlerdır $(r=22$, ve $r=16, p<05)$

Akıl hastalarının davranışlarının ne kadar rahatsızlık yaratabıleceğı sorulơuğunda, lçıne Kapanıklık (r 26, $p<006)$, Yakınma/Şıkayet $(r=24, p<01)$

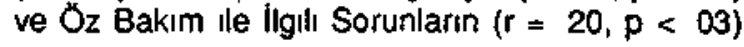


deneklerin yaşı ılerledıkçe daha çok rahatsızlık verici davranışlar olarak nitelendiği bulunmuştur.

Yaş llerledıkçe denekler, bütün faktơrlerde yer alan davranışlarta başa çıkmakta zorluk çekeceklerini belirtmişlerdir $(p<.005)$.

\section{SONUÇ}

Bu çalışmada kışılerin zihinlerindeki "akıl hastası" ortaya çıkarabilmek ıçin deneklere herhangi bir hastalık adı ya da bir vaka sunulmamıştır. Bu yözden elde edilen 7 faktơrün Türk insanının akıl hastalarına vermiş olduğu genel ozellikleri yansıttıkları düşünülebilir.

Deneklerın yarısından fazlasının $(N=94)$ akı hastası olan birısını tanıyor olması ve bu tanımanın dığer deneklere oranla bir farklılık yaratacağı beklentisı kanıtlanmamıştır. Bir akıl hastasıını tanıyıp tanımamanın hastalıkla ilgıı davranışların sıkığını, duyulabilecek rahatsızlığı ve başa çıkıp çıkamamayı belirlemekte etkısınin olmayışı ı lgi çekicıdır.

Faktörler kendı aralarında ıncelendiğinde Olumsuz Duyguların ve $\mathrm{O}_{z}$ Bakım ile ligılt Sorunların akıl hastalarından en çok beklenen davranışlar, Saldırganlığın ise en rahatsızlık yaratan davranış olduğu denekler tarafından belirtilmiştir. Başa çıkma konusunda ise denekler kendilerinı bütün faktorlerde pek fazla yeterlı görmemekte ve bu yetersizlik beklentisi deneğin yaşı artıkça artmaktadır.

Halk eğitiminde, akıl hastalarından en sıklıkla beklenen ve "Olumsuz Duygular" ve "Öz Bakımla ile Ilgili Sorunlar" konutarında bilgı vermek, akil hastalarının heterojen bır grup ve ozelıklerinin de çeşitli olduğunu vurgulamak yararlı oiabilir.

Saldırganlık en çok rahatsızlık yaratacağı düşü. nülen davranıştır. Akıl hastalarında görölebilen bu özelliğın medyada verıldığı gibı yaygın olarak görilen bır özellik olmadığı da eğıtim programlarında ışlenmeiıdır.

Yaş artıkça başa çıkabııme beklentilerınde gŏzlenen düşüş, halk eğitıminde ozeillıkle bu kesime eğımenın onemine işaret etmektedir. Yetışkin akıl hastalarının bakımını üstlenen yakınlarının yaşlıca bir kesım olabıleceğı göz onùnde tutulursa, bzellikle bakım rolünü üstlenenlere başa çıkma becerilerı üzerınde eğitım vermek yararı olabilir.

\section{KAYNAKLAR}

Arkar, H, ve Eker, D (1992) Influence of having a hospitalized mentally ill member in the family on attutudes toward mental patents in Turkey Social psychiatry and Psychiatr Epidemiology, 27, 151-155

Barrowcloud, $C$, ve Tarrier, $N$ (1987) A behavioral famuly intervention with a schizophrenc patient A case study Behavioral Psychotherapy, 15, 252-271

Eker, D (1991) Alienın ve toplumun akı hastalfkları ile igilı tutumları Alle ve Toplum, $72-79$

Link, BG (1987) Understanding labelling effects in the area of mental disorders An assessment of the effects of expectations on rejection American Socrological review, 52. $96-112$
Link, BG, Mirotznk, J, ve Cullen, FT (1991) The effectrveness of stigma coping orientations Can negative consequences of mental illness labeling be avoided? Journal of Health and Social Behavwor, 32, 302-320

Morrison. M, Man, AE, \& Drumheller, A (\$994) Multidimensional locus of control and attitudes toward mental Illness Perceptual and Motor Sklls 8, 1281-1281

Socall, OW. \& Hoitgraves, T (1992) Attitudes soward the mentally ilt The eflects of label and beliels The Socrological Quarterly, 33 (3), 435-445

Wahl, Of (1992) Mass media umages of mental itiness A review of the literature Soumal of Community Psychology, 20, 343-352 